Available online on 15.10.2020 at http://jddtonline.info
Open Access to Pharmaceutical and Medical Research
unrestricted non-commercial use, provided the original work is properly cited

Open $\odot$ Access

Research Article

\title{
Histo-Epidemiological Profile of Endometrial Cancer in the Oran Region
}

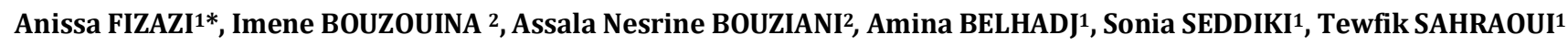

${ }^{1}$ Biology of Development and Differentiation Laboratory, Department of Biology, Faculty of Natural and Life Sciences, University of Oran1, Ahmed Ben Bella, Algeria

2 Department of Biology, Faculty of Natural and Life Sciences, University of Oran1, Ahmed Ben Bella, Algeria

\begin{abstract}
Objective: The aim of the present study is to describe the epidemiological, histopathological and therapeutic profile of endometrial can cers in the region of Oran.

Methods: We conducted a retrospective study by exploring the medical files of 25 female patients diagnosed of endometrial cancer and treated at the level of the EHU November 1, 1954's medical oncology department in Oran during the period from January 2015 to December 2019.

For data collection, we used a structured exploitation sheet to obtain necessary information. Variables were analyzed using SPSS Software Version 20.0.

Results: The median age of patients was 59 years with extremes ranging from 42 to 83 years. More than $56 \%$ of our patients were over 50 years old, $40 \%$ of the patients were nulliparous and $80 \%$ postmenopausal. The average age of menarche was $14.09 \pm 1.44$ years with extremes ranging from 12 to 17 years. The indication for anatomopathological examination was dominated by metrorrhagia (80\%).

Histopathologically, endometrioid adenocarcinoma was the most common at $75 \%$ of cases. We also note that $62.5 \%$ were classified in stage I and $37.5 \%$ in stage II. Myometrium infiltration was observed in $66.67 \%$ of cases. The basic treatment for endometrial cancer remains surgical.

Conclusion: At the end of this work, we concluded that this pathology remains essentially that of postmenopausal women. Endometrioid adenocarcinoma was the most common histologic type. This study also revealed many risk factors for endometrial cancer, such as advanced age, hypertension and nulliparity.
\end{abstract}

Keywords: Cancer, Endometrium, Epidemiology, Anathomopathology, Risk factors

Article Info: Received 13 Aug 2020; $\quad$ Review Completed 22 Sep 2020; $\quad$ Accepted 06 Oct 2020; $\quad$ Available online 15 Oct 2020

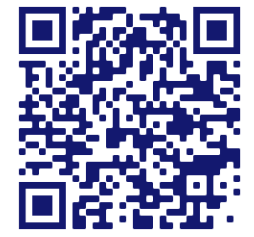

Cite this article as:

Fizazi A, Bouzouina I, Bouziani AN, Belhadj A, Seddiki S, Sahraoui T, Histo-Epidemiological Profile of Endometrial Cancer in the Oran Region, Journal of Drug Delivery and Therapeutics. 2020; 10 (5-s):143-148 http://dx.doi.org/10.22270/jddt.v10i5-s.4354

Anissa FIZAZI, Biology of Development and Differentiation Laboratory, Department of Biology, Faculty of Natural and Life Sciences, University of Oran1, Ahmed Ben Bella, Algeria

\section{INTRODUCTION}

The data from descriptive epidemiological studies of endometrial cancers around the world suggest that currently, nearly 382,100 new cases of endometrial cancer have been identified, which represents about $4.4 \%$ of new cancer cases in women.

This rate places it seventh in terms of incidence, after breast cancer, colon-rectum, lung, cervix, thyroid and skin carcinomas ${ }^{\mathbf{1}}$.

Global cancer statistics 2018 estimates that its incidence is highest in developed countries. It is 30.8 cases / 100,000 inhabitants in North America and 25.8 cases / 100,000 inhabitants in Europe in 2012. The lowest incidence is recorded in Africa; it is 2.1 cases / 100,000 inhabitants in 2012.

In Algeria, endometrial cancer has a relatively low incidence rate of 2.3 / 100,000 inhabitants.

It often affects women in the post-menopausal period, but it can also show in perimenopause and sometimes even in young women, especially when there is a background of genetic predisposition ${ }^{2}$.

The known risk factors for the disease are mainly related to steroid hormones (oestrogen and progestogen) 3,4,5.

The treatment of endometrial cancers is primarily based on surgery, which is the main therapeutic procedure allowing to 
identify the histopronostic factors and classify the tumour according to the FIGO scale. In view of these elements, an adjuvant treatment is then decided, which is based on brachytherapy of the vaginal fundus and mainly external radiotherapy6.

However, there is unfortunately a great lack of data and studies on endometrial cancer in Algeria. This is why we have chosen to carry out this study, which will be able to give a concrete idea of the histological and epidemiological characteristics of this condition in our region.

\section{Objectives}

The aim of the present study is to describe the epidemiological-clinical, histopathological and therapeutic profile of endometrial cancers in the Oran region.

At the same time, our study aims to identify the main risk factors linked to this cancer.

\section{PATIENTS AND METHODS}

We conducted a retrospective study in which we explored the medical records of 25 female patients with endometrial cancer whose treatment was carried out between January 2015 and December 2019 at the level of the EHU November 1 , 1954's medical oncology department of Oran.

All female patients diagnosed with endometrial cancer by anatomopathological confirmation were included.

Female patients with missing records of data on fundamental variables such as pathologic findings were excluded.

Data collection was made possible thanks to the development of an exploitation sheet produced especially for this purpose. This sheet allowed us to determine the distribution of the following variables in the sample studied:
- Sociodemographic variables: Data related to age, profession and the marital status of patients.

- Patient history: All the medical, surgical and family histories of patients were taken into consideration in our file.

- Clinical and radiological criteria: Ultrasound, MRI, Xray chest

- Anatomopathological criteria: Type and histological grade of the cancer

- Therapeutic criteria: Type of treatment chosen (surgery, chemotherapy, radiotherapy, etc.)

The SPSS 20.0 software (Statistical Package for the Social Sciences, IBM Corporation; Chicago, IL, August 2011) for Windows allowed us to make a descriptive analysis of each variable through calculations of average with standard deviation, frequency and percentage.

\section{RESULTS AND DISCUSSION}

\section{Epidemio-clinical aspects}

\section{Age}

Analysis of the results shows that the average age of our study population was $60.36 \pm 11.38$ years with extremes ranging from 42 to 83 years.

Figure 1 represents our sample distributed by age group, the most represented age groups are those of 51-60 years and 61-70 years; they alone represent more than half of our sample.

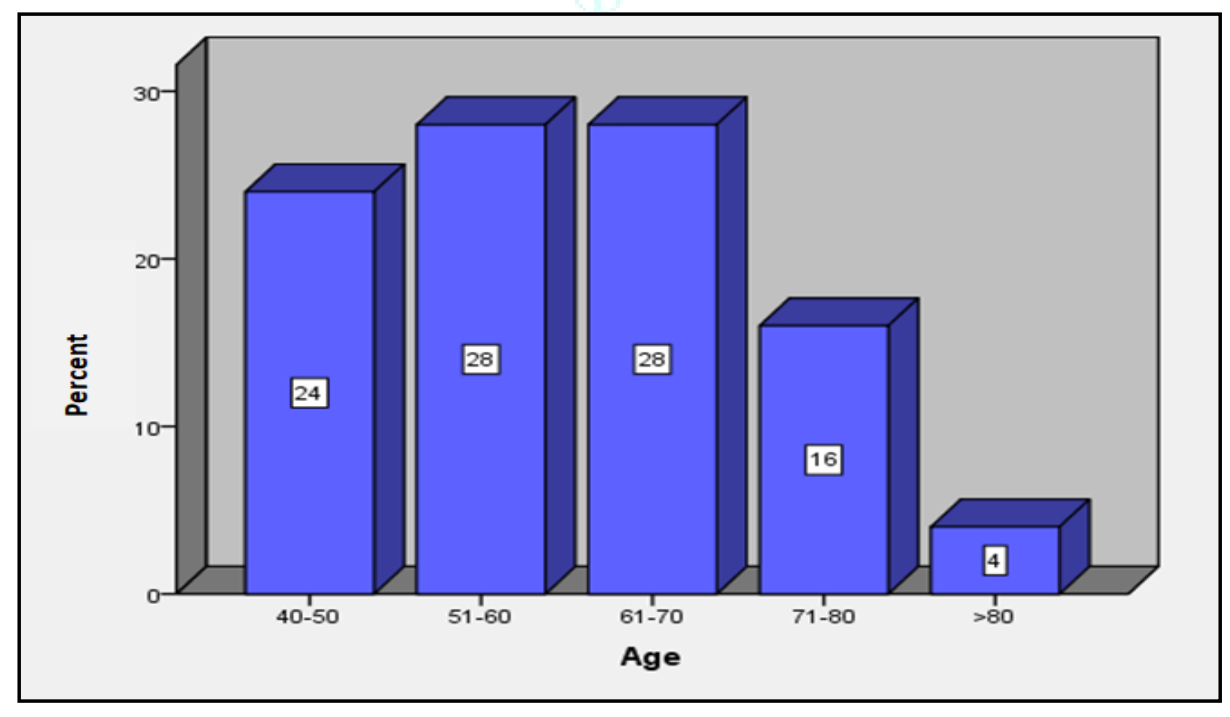

Figure 1: Distribution of patients according to age.

According to the results of various studies (Table 1), the average age lies around 60 years. The incidence rate increases with age, reaching a frequency peak between 45 and 74 years.
By comparing our results with the data in the literature, we see that our series matches the literature. 
Table 1: Average age of endometrial cancer reported by some studies.

\begin{tabular}{|c|c|c|}
\hline Serie & $\begin{array}{c}\text { Average age } \\
\text { (years) }\end{array}$ & $\begin{array}{c}\text { Extreme age } \\
\text { (years) }\end{array}$ \\
\hline Buhler and al, $2015^{7}$ & 68 & $56-82$ \\
\hline Doghri and al, $2018^{8}$ & 60 & $34-79$ \\
\hline Sando and al, $2014^{9}$ & 59 & $40-77$ \\
\hline Parsonsa and al, 201810 & 55 & $35-72$ \\
\hline Ouédraogo and al, $2011{ }^{11}$ & 56,7 & $40-79$ \\
\hline De kerdaniel and al, $2016^{12}$ & 68 & $42-80$ \\
\hline Koual and al, 201813 & 61,9 & $33-74$ \\
\hline Our serie & 60,36 & $42-83$ \\
\hline
\end{tabular}

\section{Profession}

Among the 25 women surveyed, 83.33\% were unemployed. For the remaining $16.66 \%$, they held teaching $(11.11 \%)$ or administrative $(5.56 \%)$ positions.

The predominance of these two occupations can be explained by the fact that they are the main activities carried out by women in large cities.

\section{Number of parities}

The majority of women in our study population (90\%) were married. The distribution of our patients according to their number of parities shows a predominance of multiparas (60\%), compared to nulliparas (40\%). Our results are similar to those obtained in the study by Loaec and al. (2018) ${ }^{14}$ but lower than those obtained by Yazbeck and al. (2004)15, where $89 \%$ of women with endometrial cancer were nulliparous.

\section{Age of menarche}

The data collected reveals that the average age of menarche was $14.09 \pm 1.44$ years with extremes ranging from 12 to 17 years.

Table 2 on the distribution of patients according to the age of menarche shows that it varied from 13 to 14 years in the majority of our population, i.e. $63.63 \%$ of cases.

Table 2: Distribution of patients according to the age of menarche.

\begin{tabular}{|c|c|}
\hline Age (years) & Percent (\%) \\
\hline 12 & 9,09 \\
\hline 13 & 27,27 \\
\hline 14 & 36,36 \\
\hline 15 & 9,09 \\
\hline 16 & 9,09 \\
\hline 17 & 9,09 \\
\hline
\end{tabular}

Some authors believe that the early age of menarche is associated with an increased risk of endometrial cancer and the reverse is true. Indeed, those women have an increased number of menstrual cycles compared to others, and therefore a greater exposure to estrogen.16,17.
Early menarche increases the risk of endometrial cancer by up to 9 times, compared to women whose menarche only occurs at age 15 or older 18 .

\section{Hormonal Status}

The results of our investigation on the hormonal status of our patients show a large predominance of postmenopausal patients (80\%), whereas only $20 \%$ of them were in a period of genital activity.

In the study by Felix and al (2010) $19,86 \%$ of women are postmenopausal. Likewise, in the study by Engbang and al (2015) $20,79.69 \%$ of patients were postmenopausal. The results of our series corroborate with these amounts of data.

Regarding the medical history of our patients, $67 \%$ did not have one. As for the others, the most common medical history found was Arterial Hypertension (Hypertension) as shown in Table 3.

Table 03: Distribution of patients according to their medical history.

\begin{tabular}{|l|l|}
\hline Reason for consultation & Percent (\%) \\
\hline HT & 50 \\
\hline Diabetes & 14,29 \\
\hline Cancers & 21,43 \\
\hline Hypothyroidism & 7,14 \\
\hline Obesity & 7,14 \\
\hline
\end{tabular}

In our series, hypertension presents $50 \%$ of the medical history, which is in agreement with the literature results. A comparative study (between the 2 histological types of the endometrium), conducted by Malik and al. (2016) 21 , shows that the incidence of arterial hypertension was high in both groups of patients: $75 \%$ in the group of patients with type 2 cancer, and $56.2 \%$ in the group of patients with type 1 endometrial cancer.

It is also reported that in the present study, $14.29 \%$ of patients were diabetic. Diabetes is also a risk factor, according to Munstedt and al (2004) 22 since hypercorticism is increased by hyperinsulinism, which disturbs oestrogen metabolism. 
For Boruta II and al (2009)23, Breast, ovarian and colorectal cancers were the three most common malignant tumours, Breast and colorectal cancers were more common in type II cases, while ovarian cancer was more common in type I cases. In our series, two patients had ovarian cancer.

In addition, $7.14 \%$ of the patients suffered from obesity in our sample. According to Amant and al (2007) 24, a body mass index (BMI) greater than $25 \mathrm{~kg} / \mathrm{m} 2$ doubles the risk of endometrial adenocarcinoma, and a BMI greater than $30 \mathrm{~kg} /$ $\mathrm{m} 2$ triples the risk.

\section{Family history}

In our series, four patients had a family history of cancer, i.e. $16 \%$ of cases. According to Win and al $(2015)^{25}$, the risk of endometrial cancer is approximately $17 \%$ in women with a first-degree family member with colorectal cancer.

These associations indicate the existence of genetic factors in endometrial cancer. Some studies have reported that the association between family history and risk of endometrial cancer is stronger if more than one family member is affected and if the affected members are closer. ${ }^{26,27}$.

\section{Surgical history}

Regarding the surgical history in our sample, only one patient had undergone a thyroidectomy.

\section{Circumstances of discovery}

The distribution of patients according to the circumstances of discovery of endometrial cancer is shown in Table 4. This table reveals that metrorrhagias, alone or associated, were the most common reason for consultation; the latter is found in $80 \%$ of patients. In a study by Rossard and al. (2013), metrorrhagia represented $77 \%$ of symptoms, and in another study by Nouni and al. (2010), metrorrhagia represented $89 \%$ of the reasons for consultation 28,29 .
Pelvic pain was found in $20 \%$ of our patients, this is a higher frequency than that of the series by Rossard and al. (2013) which was $2.9 \%$ - and lower than that of the series by Nouni and al. (2010) where pelvic pain accounted for $30 \%$ of cases.

In our sample, leucorrhoea is present in $8 \%$ of cases while in the series by Rossard and al. (2013), leucorrhoea only represented $3.7 \%$. In the series by Nouni and al. (2010), leucorrhoea accounted for $29 \%$.

Table 4: Distribution of patients according to the circumstances of discovery of endometrial cancer.

\begin{tabular}{|l|l|}
\hline Reason for consultation & Percent (\%) \\
\hline Metrorrhagias & 27 \\
\hline Pelvic pain & 20 \\
\hline Leucorrhoea + Metrorrhagia & 8 \\
\hline
\end{tabular}

\section{Ultrasound}

Ultrasound showed endometrial thickening in $66.67 \%$ of patients and infiltration of the myometrium in $25 \%$ of cases (Figure 2).

According to several published series, a simple measurement of endometrial thickness can reliably discriminate between women at low or high risk of endometrial cancer 30,31 .

According to Bazot and al. (2002), the thickness of the endometrium is greater than $4 \mathrm{~mm}$. The ultrasound allows to discover in postmenopausal women with abnormal bleeding a pathology (benign or malignant); the greater the thickness of the endometrium measured in ultrasound, the higher the risk of cancer 32 .

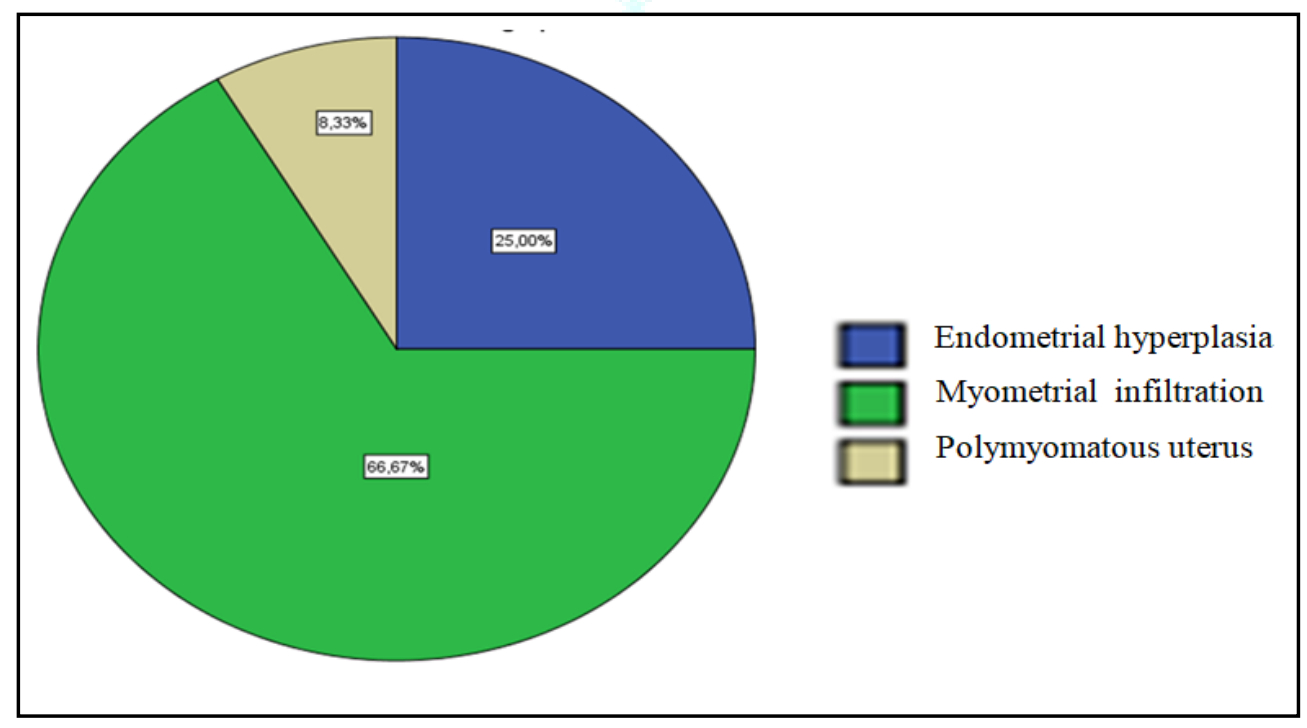

Figure 2: Distribution of patients according to ultrasound results.

\section{Histopathological aspect}

\section{The histological type}

The results of blind biopsy endometrial curettage are shown in Table 5. We note that the most commonly found histological type was endometrioid adenocarcinoma (75\%), followed by tubulo-papillary adenocarcinoma (15\%) and carcinosarcoma (10\%).
This predominance of adenocarcinoma corroborates with the data in the literature. In the series by Engbang and al. $(2015)^{33}$, adenocarcinoma was the most common histological type with 120 cases $(68,18 \%)$, followed by squamous cell carcinomas, 22 of the cases (12.50\%). N'Dah and al. $(2014)^{34}$ found $91.67 \%$ of cases of adenocarcinoma, and Sando and al. (2014) 35 reported that $90.5 \%$ of endometrial cancers were adenocarcinomas. 
In the West, adenocarcinomas have been estimated at $80 \%$ (Colombo and al., 2013) ${ }^{36}$.

Table 5: Distribution of patients according to the histological type of endometrial cancer.

\begin{tabular}{|l|l|}
\hline Histological type & Percent (\%) \\
\hline Endometriotic adenocarcinoma & 75 \\
\hline Tubulopapillary adenocarcinoma & 10 \\
\hline Endometrial stromal sacroma & 15 \\
\hline
\end{tabular}

\section{Histological grade}

On histological analysis, the predominant grade was grade 1 in $62.5 \%$ of cases, followed by grade $2(37.5 \%)$.
In the Doghri and al. Study (2015), the predominant histological grade was grade 1 (31 cases, or $60 \%$ ), followed by grade 2 (18 cases, 34\%) and high-guard carcinomas (13 cases, $20 \%$ ).

\section{Treatments}

\section{Surgical treatment}

The surgical procedure consisted of a total hysterectomy without adnexal conservation in $86.67 \%$ of cases (Table 6).

According to Brémond and al. (2001) 37, Surgery is the standard treatment for endometrial cancer as long as the stage and patient's condition allow it. Standard surgery is a total hysterectomy with bilateral adnexectomy. The performance of additional procedures (lymphadenectomy, omentectomy) depends on the clinical stage, the histological type and the grade.

Table 6: Distribution of patients according to the surgical procedures performed in our series.

\begin{tabular}{|l|l|}
\hline Surgical procedure & Percent (\%) \\
\hline Total hysterectomy with bilateral adnexectomy & 86,67 \\
\hline Total hysterectomy without adnexal conservation & 6,67 \\
\hline Enlarged colpohysterectomy & 6,67 \\
\hline
\end{tabular}

\section{Radiotherapy}

Adjuvantly, radiotherapy was performed in 02 cases, i.e. $8 \%$ of cases.

According to Uzan and al. (2012), the indications for adjuvant radiotherapy depend on histological results, but also on the extent of lymph node staging, with recent integration of the sentinel lymph node procedure to limit surgical morbidity. The benefit of adjuvant treatments must be assessed in comparison with their survival benefit (survival without recurrence or overall survival), but also with their toxicity. The European recommendations have attempted to integrate this double assessment ${ }^{38}$.

\section{Chemotherapy}

Chemotherapy was carried out in 03 cases as an adjuvant, i.e. in $13 \%$ of cases.

According to some studies, chemotherapy has a limited place in the treatment of endometrial cancers; it only applies to advanced or metastatic stages, to recurrences and to seropapillary forms ${ }^{39}$. The indication and the modalities in these situations must take into account the age of the patient, the associated diseases and the side effects of the proposed treatments.

According to Gücer and al. (2005), the most active drugs are platinum salts, anthracyclines, fluorouracil and more recently paclitaxel 40 .

\section{CONCLUSION}

Despite its low incidence in Algeria, endometrial cancer is one of the most common gynaecological cancers in the world.

The present study has shown us that endometrial cancer in the Oran region remains essentially that of postmenopausal women; the average age in our series was 60 years. Patients aged 51 to 70 were the most affected.
Postmenopausal metrorrhagia is the most frequent circumstance of discovery and adenocarcinoma was the most common histological type.

The basic treatment for endometrial cancer remains surgical.

Endometrial cancer is associated with several risk factors such as advanced age in patients, hypertension and nulliparity.

Finally, the prognosis of endometrial cancer remains better if the diagnosis is made at an early stage, hence the importance of raising awareness among women on the risks and symptoms of endometrial adenocarcinoma, especially postmenopausal bleeding which presents a real alarm signal.

\section{ACKNOWLEDGMENTS}

We express our gratitude to the staff of the EHU November 1,1954 's medical oncology department in Oran. We are grateful to HADJARI Meriem for English language revision.

\section{REFERENCES}

1- Ferlay J, Colombet M, Soerjomataram I, Mathers C , Parkin D $M$, Piñeros $M$ et al. Estimating the global cancer incidence and mortality in 2018: GLOBOCAN sources and methods. International journal of cancer . 2019; 144 (8):1941-1953.

2- Pomel C, Perbet E, Dauplat J, Martinez A, Canis M, Philippe A C et al. Le curage lombo-aortique en question (s)... Gynécologie Obstétrique \& Fertilité. 2013; 5 (41):273-274.

3- Lyoke CA, Ugwu GO. Burden of gynaecological cancers in developing countries. World J Obstet Gynecol. 2013; 2(1):1-7 5.

4- Sancho-Garnier H. Epidémiologie des cancers gynécologiques : utérus, ovaire, vulve, vagin. In: Riethmuller D, Carcopino X (eds) Cancers gynécologiques pelviens. Elsevier Masson, Paris, 2013; 85-99 8.

5- Sénéchal C, Cottereau E, de Pauw A, et al . Les facteurs de risque génétiques et environnementaux des cancers de l'endomètre. Bull Cancer. 2013; 102 (3):256-69 
6- Peignaux K, Truc G, Blanchard N, Créhange G, Maingon P. Cancer de l'endomètre de stade I. Cancer/Radiothérapie . 2008; 12 (6-7):625-629.

7- Buhler J, Routiot T, Polet-Lefebvre K, Morel O. Évaluation de l'échographie et de l'IRM dans la stadification des tumeurs de l'endomètre de stage I. Gynécologie Obstétrique \& Fertilité . 2015; 43(4):329-331.

8- Doghri R, Yahyaoui Y, Gabsi A, Driss M, Boujelbenea N, Charfia L. Les carcinomes de l'endomètre: étude anatomopathologique et histopronostique à propos de 62 cas dans un centre du Nord tunisien. Annales de Pathologie. Elsevier Masson, 2018 : 85-91.

9- Sando Z, Fouogue J T, Fouelifack F Y, Fouedjio J H, Mboudou E T, Essame JL. Profil des cancers gynécologiques et mammaires à Yaoundé-Cameroun. Pan African Medical Journal. 2014; 17 (1).

10- Parsonsa L H P, Pedersenb R, Richardsona D L, Khoc K L. The prevalence of occult endometrial cancer in women undergoing hysterectomy for benign indications. European Journal of Obstetrics \& Gynecology and Reproductive Biology. 2018; 223:108-112.

11- Ouédraogo A S, Sanou-Lamien A M, Ouédraogo-Tiendrébéogo R, Ramde N, Konsegre V, Ido F, Goumbri-Lompo O M, Soudre $B$ R. Aspects histoépidémiologiques du cancer de l'endomètre à Ouagadougou.. Journal Africain du Cancer/African Journal of Cancer. 2011; 3(4):251-255.

12- De Kerdaniel O, Bodya N, Davoinea E, Foucher F, Henno S, Tavenardc A. et al. Application des recommandations dans la prise en charge du cancer de l'endomètre en pratique clinique. Étude rétrospective bretonne. Journal de Gynécologie Obstétrique et Biologie de la Reproduction. 2016; 45(9):1045-1053.

13- Koual M, Ngo C, Girault A, Le'curu F, Bats A. Endometrial cancer in the elderly: does age influence surgical treatments, outcomes, and prognosis?. Menopause. 2018; 25( 9):968-976.

14- Loaec C, Vaucel E, Darnis E, Lopes P, Selmes G, Jaffre I et al. Clinical practice for morbidly obese endometrial cancer patients: A french multicentric study. Bulletin du cancer. 2018; 105(5):441-449.

15- Yazbeck C, Dhainaut C, Thoury A, Driguez P, Madelenat P. Conservative treatment of endometrial cancer and atypical hyperplasia. Gynecologie, Obstetrique \& Fertilite. 2004; 32(5):433-441.

16- Reis N, Beji N K. Risk factors for endometrial cancer in Turkish women: results from a hospital-based case-control study. European Journal of Oncology Nursing. 2009; 13(2):122-127.

17- Rice L W. Hormone prevention strategies for breast, endometrial and ovarian cancers. Gynecologic Oncology . 2010; 118(2):202-207.

18- Fujita M, Tase T, Kakugawa Y, Hoshi S, Nishino Y, Nagase S et al. Smoking, earlier menarche and low parity as independent risk factors for gynecologic cancers in Japanese: a case-control study. The Tohoku journal of experimental medicine. 2008; 216(4):297-307.

19- Felix AS, Weissfeld JL, Stone RA, Bowser R, Chivukula M, Edwards RP, Linkov F. Factors associated with Type I and Type II endometrial cancer. Cancer Causes Control. 2010;21(11):1851-6.

20- Engbang N J P, Essome H, Tchente N C, Essam S J D, Elono F A $\mathrm{M}$, Ateba $\mathrm{G} \mathrm{R}$ et al. Cancer de l'endomètre au Cameroun : profil histo-épidémiologique de 176 cas. Journal Africain du Cancer/African Journal of Cancer. 2015; 7, (4):218-222.

21- MALIK, Tahira Y., et al. Comparison of risk factors and survival of type 1 and type II endometrial cancers. Pakistan journal of medical sciences. 2016; 32(4):886.

22- Münstedt K, Grant P, Woenckhaus J, Roth G, Tinneberg $\mathrm{H}$. Cancer of the endometrium: current aspects of diagnostics and treatment. World journal of surgical oncology. 2004; 2(1):1-17.

23- Boruta DM, Gehrig PA, Fader AN, Olawaiye AB. Management of women with uterine papillary serous cancer: a Society of Gynecologic Oncology (SGO) review. Gynecologic oncology. 2009; 115( 1):142-153.
24- Amant F, Moerman P, Neven P, Timmerman D, Van Limbergen E, Vergote I. Treatment modalities in endometrial cancer. Current opinion in oncology. 2007; 19(5):479-485.

25- Win A, Reece J C, Ryan S. Family history and risk of endometrial cancer: a systematic review and metaanalysis. Obstetrics \& Gynecology. 2015; 125(1):89-98.

26- Seger H M, Seger H M, Soisson A P, Dodson M K, Rowe K G, Cannon-Albright L A, et al. Familial clustering of endometrial cancer in a well-defined population. Gynecologic oncology. 2011; $122(1): 75-78$.

27- Bharati R, Jenkins M, Lindor N , Marchand L, Gallinger S, Haile R, Newcomb P, Hopper J. Does risk of endometrial cancer for women without a germline mutation in a DNA mismatch repair gene depend on family history of endometrial cancer or colorectal cancer?. Gynecologic oncology. 2014; 133(2):287-292.

28- Rossard L, Rua C, Duquesne M, Vildé A, Marret H, Body G, et al. Reliability of imaging modalities for preoperative assessment of patients with endometrial carcinoma. Gynecologie, Obstetrique \& Fertilite. 2013; 41(11):641-647.

29- Nouni K, Diakité A, Masbah W, Kebdani T, Hassouni K, Benjaafer $\mathrm{N}$, et al. Traitements adjuvants et rôle de la radiothérapie dans le cancer de l'endomètre. Cancer/ Radiothérapie. 2010; 6(14):656.

30- Gull B, Karlsson B, Milsom I, Granberg S. Can ultrasound replace dilation and curettage? A longitudinal evaluation of postmenopausal bleeding and transvaginal sonographic measurement of the endom etrium as predictors of endometrial cancer. American journal of obstetrics and gynecology. 2003; 188(2):401-408.

31- Dueholm M, Forman A, Jensen M L, Laursen H, Kracht P. Transvaginal sonography combined with saline contrast sonohysterography in evaluating the uterine cavity in premenopausal patients with abnormal uterine bleeding. Ultrasound in Obstetrics and Gynecology: the Official Journal of the International Society of Ultrasound in Obstetrics and Gynecology.2001; 18(1):54-61.

32- Bazot M., Bendavid S, Robert Y. Place de l'échographie doppler et de l'IRM pour le diagnostic et le bilan d'extension des cancers de l'endomètre. La Lettre du gynécologue. 2002, 274:24-26.

33- Engbang N J P, Essome H, Tchente N C, Essam S J D, Elono F A $\mathrm{M}$, Ateba G R et al. Cancer de l'endomètre au Cameroun : profil histo-épidémiologique de 176 cas. Journal Africain du Cancer/African Journal of Cancer [en ligne]. 2015; 7(40):218-222.

34- N’Dah K J, Doukoure B, Troh E, Aman N A, Koffi K E, Kouamé A $\mathrm{D}$, et al. Epidemiological and Histological Aspects of Women Genital Cancers in Côte d'Ivoire. Open Journal of Obstetrics and Gynecology

35- Sando Z, Fouogue J T, Fouelifack F Y, Fouedjio J H, Mboudou E T, Essame JL. Profil des cancers gynécologiques et mammaires à Yaoundé-Cameroun. Pan African Medical Journal[en ligne]. $2014 ; 17: 1$.

36- Colombo N, Preti E, Landoni F, Carinelli S, Colombo A, Marini C, Sessa C. Endometrial cancer: ESMO Clinical Practice Guidelines for diagnosis, treatment and follow-up. Annals of oncology. 2013; 24(suppl 6):VI33-VI38.

37- Brémond A, Bataillard A, Thomas L, Achard J L, Fervers B, Fondrinier E, Lansac J, Bailly C, Hoffstetter S, Basuyau J P, d'Anjou J, Descamps P, Farsi F, Guastalla J P, Laffargue F, Rodier JF, Vincent P, Pigneux J.Br J Cancer. 2001; 84(Suppl 2):31-36.

38- Uzan C, Gouy S, Pautier P, Lhommé C, Duvillard P, Haie-Meder $\mathrm{C}$, et al. French recommendations for endometrial cancer 2010: clinical use and questions still debated. Bulletin du cancer. $2012 ; 99(1): 107$.

39- Despierre E, Moerman P, Vergote I, Amant. Is there a role for neoadjuvant chemotherapy in the treatment of stage IV serous endometrial carcinoma?. International Journal of Gynecologic Cancer. 2006 ; 16(Suppl 1):273-277.

40- Gücer F, Yilmaz O, Balkanli-Kaplan P, Ali Yüce M. Complete remission of an endometrial carcinoma with bilateral multiple pulmonary and extrapelvic metastases treated by surgery and chemotherapy consisting of paclitaxel and carboplatin. International Journal of Gynecologic Cancer. 2005; 15(6). 